\title{
Impact of Quebracho Tannins Supplementation on Productive and Reproductive Efficiency of Dairy Cows
}

\author{
Marwa F. A. Attia'1, Adel N. M. Nour El-Din'1, Samir Z. El-Zarkouny²,2, Hani M. El-Zaiat1, \\ Moustafa M. Zeitoun ${ }^{1,3^{*}}$, Sobhy M. A. Sallam ${ }^{1}$
}

\begin{abstract}
${ }^{1}$ Department of Animal and Fish Production, Faculty of Agriculture, Alexandria University, Alexandria, Egypt
${ }^{2}$ Department of Arid Land Agriculture, Faculty of Meteorology, Environment and Arid Land Agriculture, Jeddah, Saudi Arabia ${ }^{3}$ Department of Animal Production and Breeding, College of Agriculture and Veterinary Medicine, Qassim University, Qassim, Saudi Arabia
\end{abstract}

Email: ^mmzeitoun@yahoo.com

How to cite this paper: Attia, M.F.A., El-Din, A.N.M.N., El-Zarkouny, S.Z., ElZaiat, H.M., Zeitoun, M.M. and Sallam, S.M.A. (2016) Impact of Quebracho Tannins Supplementation on Productive and Reproductive Efficiency of Dairy Cows. Open Journal of Animal Sciences, 6, 269288.

http://dx.doi.org/10.4236/ojas.2016.64032

Received: August 1, 2016

Accepted: September 27, 2016

Published: September 30, 2016

Copyright $\odot 2016$ by authors and Scientific Research Publishing Inc. This work is licensed under the Creative Commons Attribution International License (CC BY 4.0).

http://creativecommons.org/licenses/by/4.0/

\section{(c) (i) Open Access}

\section{Abstract}

This study was conducted to investigate effects of supplementing two doses of quebracho tannins (QT; 100 or $200 \mathrm{~g} /$ cow/d; $\mathrm{QT}_{100}$ or $\mathrm{QT}_{200}$ ) pre and post parturition to thirty Holstein dairy cows on Dry Matter Intake (DMI), milk yield and composition, blood metabolites and reproductive performance for 12 weeks. There were no significant changes in DMI due to QT at transition period of dairy cows. QT supplementation at either level decreased $(\mathrm{P}<0.004)$ milk yield, Fat Corrected Milk (FCM) and Feed Efficiency (FE; $\mathrm{P}<0.016$ ) compared to untreated dairy cows. The supplementation of QT had no significant effect on milk fat, lactose percentage and protein and solid nonfat (SNF) yield, while protein percentage increased significantly in treated compared to control cows. Treatment time had significant effects on milk composition. The only time $\times$ treatment interactions were found on milk fat and protein percentages. Supplementation with QT tended to decrease $(P>0.05)$ the total number of ovarian follicles, number of large follicles, diameter of largest follicle, number of small follicles, number and diameter of corpus luteum, and progesterone concentration. The inclusion of QT increased days open and number of services per conception, which consequently decreased conception rate, compared to the control cows. $\mathrm{QT}_{100}$ decreased $(\mathrm{P}<0.05)$ serum total protein, globulin, glucose and triglycerides concentrations as compared with their values in control cows. Thus, the supplementation of commercial QT to dairy cows at their transition period had negative impacts on productive and reproductive performance. 


\section{Keywords}

Quebracho Tannin, Feed Intake, Milk Yield, Follicular Dynamics, Conception Rate

\section{Introduction}

One of the common feed additives is antibiotics, e.g., monensin, which is fed to the animals to prevent disease and metabolic disorders, improve FE and reduce energy and protein losses in the rumen. In 2006, the European Union banned the use of antibiotics in livestock feeds due to probable risk to human health; antibiotic resistant bacteria may pass to human through animal products [1]. Therefore, scientists have become interested in evaluating other alternatives to control specific microbial populations in order to modulate rumen fermentation [2].

The European Union Directive EC 1831/2003 provided an opportunity to exploit plants, plant extracts and plant secondary metabolites (i.e., tannins, essential oils, saponins, flavonoids) as natural alternatives to enhance livestock productivity and reduce their impact on the environment by reducing environment pollutants such as methane $\left(\mathrm{CH}_{4}\right)$ in fermentation gases, as well as $\mathrm{P}$ and $\mathrm{N}$ in manure [3]. Plant Secondary Compounds (PSC) are biologically active molecules not involved in primary biochemical processes such as plant growth, development and reproduction. Most of PSC possess biological activity on the microorganisms, i.e. they affect some animal metabolic processes and/or the growth rate of some microorganisms [4]. For this reason, drug and animal nutrition companies routinely screen bioactive compounds of plants in order to obtain new drugs or feed additives [5].

Tannins are naturally occurring as PSC that are present in many plant species commonly consumed by ruminants. Tannins are generally defined as water soluble polymeric phenolics that precipitate proteins and are classified into hydrolysable and Condensed Tannins (CT) [6].

A unique chemical property of tannins is their affinity to bind to feed proteins and thereby reduce excessive breakdown of protein in rumen [7] and increase availability of high quality protein for absorption in the lower gut of ruminants [8]. By eating tannins dietary protein is made unavailable for ruminal digestion until it reaches the more acidic abomasum, and the modest amounts of tannins improve the protein nutrition of ruminants [9]. In addition to protecting feed proteins from rumen degradation, tannins also play significant roles in the prevention of bloat in ruminants by binding to proteins in the rumen [10], reduce $\mathrm{N}$ discharges into the environment [11], suppress intestinal parasites [12], lessen emission of greenhouse gases such as methane from animals [13], enhance immune responses [14], improve reproductive efficiency [15] and improve milk production and wool growth [16].

However, the supplementation of CT extract in lactating dairy diets has not been extensively investigated, the literature lacks information on how ruminal fermentation characteristics are altered depending upon dietary composition, particularly forage-to- 
concentrate ratio, which is considered as one of the main driving forces directly affecting ruminal fermentation and production performance of lactating dairy cows. Therefore, the objectives of this study were to investigate the effect of different levels of commercial QT supplementation on productive and reproductive performance of dairy cows under fixed ovulation synchronization protocol.

\section{Materials and Methods}

This experiment was carried out at the Milk Production Unit, Department of Animal and Fish Production, Faculty of Agriculture, Alexandria University. All experimental procedures and sample analyses involving animal care were conducted and followed the guidelines approved by the official animal care committee.

\subsection{Animals, Treatment Diets and Experimental Design}

Thirty late pregnant ( 2 - 3 weeks before parturition) Holstein multiparous dairy cows were randomly allotted into three groups as follows: G1; (Control, C) in which cows given normal diet without supplement, $\mathrm{G} 2\left(\mathrm{QT}_{100}\right)$ cows given normal diet and 100 $\mathrm{g} / \mathrm{hd} / \mathrm{d}$ of QT and G3 $\left(\mathrm{QT}_{200}\right)$ cows given normal diet plus $200 \mathrm{~g} / \mathrm{hd} / \mathrm{d}$. Treatment lasted for 12 consecutive weeks. Cows were housed in open semi-shaded barns and feed was offered at 0600, 1200 and $1800 \mathrm{~h}$ and had free access to fresh water. Throughout the experiment, cows were fed on the normal diet comprised of (based on \% DM) 40\% green forage (Trifolium alexandrinum) and $60 \%$ concentrate mixture formulated to meet the NRC [17] recommendations for pregnant and early lactating cows. The ingredients and chemical composition of concentrate mixture are shown in Table 1. Quantities of feed offered and orts were recorded daily, and adjusted to allow for $10 \%$ daily intake to measure daily DMI. Cows were milked 3 times daily at 0600, 1100 and $1900 \mathrm{~h}$, and milk yield for individual cows was recorded weekly. Feed efficiency was calculated from the following equation: $\mathrm{FE}=$ Milk Yield/DMI.

\subsection{Sampling and Chemical Analysis}

Feeds and orts were sampled biweekly throughout the trial. All samples were dried at $55^{\circ} \mathrm{C}$ in a forced-air oven, ground with a Wiley mill grinder to pass through a $1 \mathrm{~mm}$ stainless steel screen and then analysed for dry matter (DM), organic matter (OM), ether extract (EE) and crude protein (CP) according to the analytical procedures of [18]. Neutral detergent fiber (NDF) [19] and acid detergent fiber (ADF) [20] were determined in sequential analyses using an Ankom fibre analyzer (Fiber Analyzer A200; Ankom Technology, NY, USA). Milk samples were collected biweekly for proximate analysis for milk fat, protein, lactose, SNF and ash concentrations using infrared method (EKOMILK-M ultrasonic milk analyzer, EON Trading INC, Bulgaria, 2000). Fat corrected milk (FCM) calculated as milk yield $(\mathrm{kg})^{\star} 0.4+$ fat yield $(\mathrm{kg})^{\star} 15$. Energy corrected milk $(\mathrm{ECM})$ was calculated as $0.327^{\star}$ milk yield $(\mathrm{kg})+12.95^{\star}$ fat yield $(\mathrm{kg})+$ $7.20^{\star}$ protein yield $(\mathrm{kg})$.

Blood samples were collected via coccygeal venipuncture into heparinized tubes on 
Table 1. Ingredients and chemical composition of experimental diet fed to dairy cows.

\begin{tabular}{|c|c|c|c|}
\hline \multirow{2}{*}{\multicolumn{2}{|c|}{ Ingredient (g/kg DM) }} & \multicolumn{2}{|c|}{ Concentrate mixture } \\
\hline & & Pregnant cows & Lactating cows \\
\hline Ground yellow corn & & 400 & 300 \\
\hline Wheat bran & & 290 & 250 \\
\hline Cottonseed meal & & 200 & 300 \\
\hline Soybean meal & & 80 & 120 \\
\hline Limestone & & 18 & 18 \\
\hline $\mathrm{NaCl}$ & & 10 & 10 \\
\hline Mineral mixture ${ }^{1}$ & & 2 & 2 \\
\hline Chemical composition (g/kg DM) & T. alexandrinum & & \\
\hline $\mathrm{OM}$ & 887 & 912 & 899 \\
\hline $\mathrm{CP}$ & 148 & 148 & 181 \\
\hline $\mathrm{EE}$ & 17.0 & 34 & 37 \\
\hline $\mathrm{NDF}$ & 528 & 463 & 441 \\
\hline $\mathrm{ADF}$ & 459 & 211 & 192 \\
\hline Hemicellulose & 69 & 252 & 249 \\
\hline $\mathrm{RDP}^{21}$ & 720 & 615 & 615 \\
\hline RUP $^{21}$ & 280 & 385 & 385 \\
\hline
\end{tabular}

${ }^{1}$ Contained (per kg DM): $12.58 \mathrm{~g}$ Magnesium sulfate, $3.2 \mathrm{~g}$ Ferrous sulfate, $0.081 \mathrm{~g}$ calcium iodide, $3.2 \mathrm{~g}$ Copper sulfate, $0.2 \mathrm{~g}$ Cobalt sulfate, $9.3 \mathrm{~g}$ Zinc sulfate, $0.4 \mathrm{~g}$ Sodium selenite, $9.4 \mathrm{~g}$ Magnesium chloride, Carrier on sodium chloride to kg (Dyno Vet Company, Alexandria, Egypt). OM: organic matter; CP: crude protein; EE: ether extract; NDF: neutral detergent fiber; ADF: acid detergent fiber; RDP: rumen degradable protein; RUP: rumen un-degradable protein; Calculated according to Feedipedia [21].

days 10, 30, 50 and 60 postpartum for biochemical assays. Whereas, blood progesterone was determined in samples collected on days 60 ( $1^{\text {st }} \mathrm{GnRH}$ injection), $67\left(\mathrm{PGF}_{2 \alpha}\right.$ injection) and 69 (2nd GnRH injection) postpartum. Blood samples were immediately centrifuged at $3000 \mathrm{rpm}$ for $20 \mathrm{~min}$ at $4^{\circ} \mathrm{C}$, plasma was harvested and kept frozen at $-20^{\circ} \mathrm{C}$ until further analysis. Plasma total protein, albumin, urea, glucose, triglycerides, cholesterol and creatinine concentrations were spectrophotometrically analyzed (Spectrophotometer Alfa-1101, Labnics Equipment, USA) using commercial kits (Stanbio Diagnostics, Boerne, TX, USA). Globulin content of each serum sample was mathematically calculated by subtracting albumin by total protein concentration. Serum progesterone concentration was determined enzymatically by commercial kits using EnzymeLinked Immunosorbent Assay (ELISA) reader (Stat Fax 2100 Microplate Reader, Awareness Technologies Inc., USA).

\subsection{Ovulation Synchronization}

Cows were synchronized for ovulation according to OvSynch protocol that consisted of two injections of $\mathrm{GnRH}$ analogue equivalent to $2.5 \mathrm{ml}\left(10 \mu \mathrm{g}\right.$ Buserelin; Receptal ${ }^{\oplus}$, In- 
tervet International B.V. Boxmeer, Holland) 9 days apart and one injection of $\mathrm{PGF}_{2 \alpha}$ equivalent to $500 \mu \mathrm{g}$ Cloprostinol (Estrumate ${ }^{\circledR}$, Schering-Plaugh Animal Health, Germany) given $48 \mathrm{~h}$ prior to the second injection of GnRH. Cows were artificiality inseminated with frozen semen $16-20 \mathrm{~h}$ after the second injection of GnRH (TAI). The first $\mathrm{GnRH}$ injection was given at random stages of the estrous cycle of lactating cows on day 60 postpartum.

\subsection{Ultrasound Examination}

Ovarian activities and pregnancy diagnosis were examined by using ultrasonography examination. A real time B-mode scanner (FALCO) equipped with transrectal multi frequency ( 5 and $7.5 \mathrm{MHz}$ ) linear array probe was used. Cows were deprived from feed for 12 hours before examination. The probe was gently inserted into the rectum until the anechoic content of the bladder become visible on the monitor then the probe was rotated $90^{\circ}$ clockwise and $180^{\circ}$ counterclockwise across the reproductive tract until both ovaries and uterine horns were scanned. Size and location of the follicles and corpora lutea on the ovaries were mapped and recorded. Pregnancy diagnosis was carried out thirty five days after insemination. Detection of an anechoic uterus, allantoic fluids or embryo was considered positive signs of pregnancy. Figure 1 presents the experimental procedure applied on dairy cows.

\subsection{Ovarian Activities and Their Implications}

The total number of follicles $\geq 2 \mathrm{~mm}$ in each ovary and diameter of each follicle were recorded. Follicles were classified into three categories according to their sizes; small (2 - $3 \mathrm{~mm}$ ), medium ( $3-5 \mathrm{~mm}$ ) and large ( $\geq 5 \mathrm{~mm}$ ). Ovulation was confirmed by disappearance of the largest follicle or presence of luteal structure (CL).

\subsection{Reproductive Performance}

Pregnancy was diagnosed by transrectal ultrasonography 35 days after insemination and confirmed manually by rectal palpation of the uterus on days 40 - 50. Cows returning to estrus were inseminated according to the routine protocol practiced in the farm.

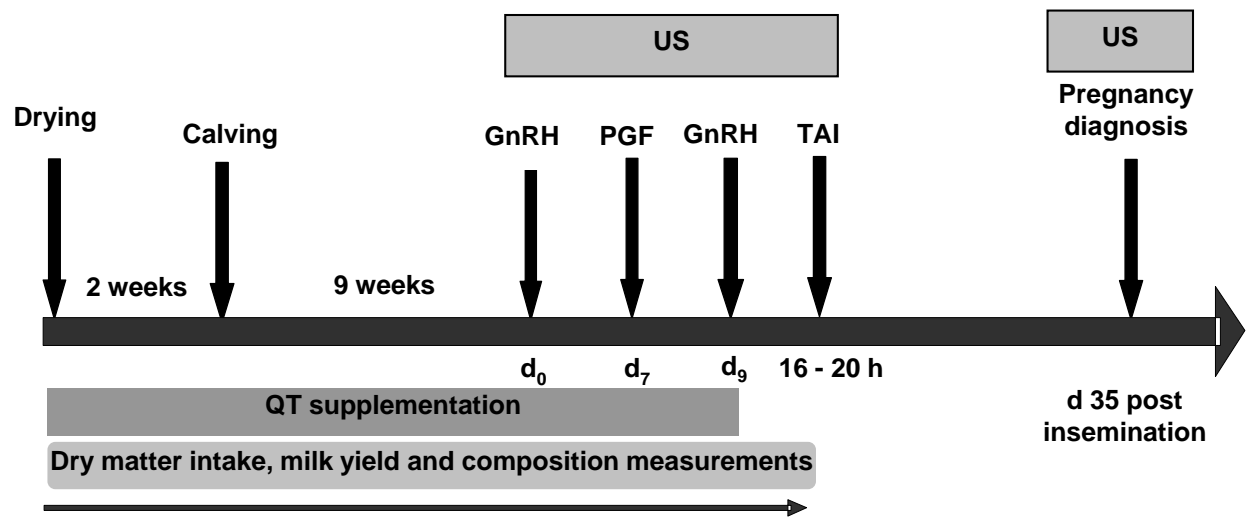

Figure 1. Diagrammatic presentation of the experimental design. 
Conception rate (CR), overall pregnancy rate (PR), number of services per conception (NSPC) and days open (DO) were also recorded.

\subsection{Statistical Analysis}

All data were statistically analyzed as a completely randomized design with 3 treatments with repeated measures over time using the MIXED procedure of SAS (version 9.2) [22]. The best fit covariance structure was autoregressive 1 (AR1). The LSMEANS option was used to generate individual treatment means. Effects of treatment, week and the interaction of treatment $x$ week with cow being the random effect were defined by the F-test of ANOVA. The used model was as follow:

$$
Y=\mu+Q_{i}+T_{j}+(Q T)_{i j}+A k t+E_{i j k}
$$

where: $\mu$ is the overall mean, $Q_{i}$ is the fixed effect of the treatment $\left(i=1-3\right.$ ); $T_{j}$ is the fixed effect of the time $(j=1-3)$; $(Q T)_{i j}$ is the interaction of treatment $\times$ time; $A_{k t}$ is random effect of the animal (within treatment) and $E_{i j k}$ is the residual error. Comparisons among treatments were performed by Tukey's test. Significant differences were considered at $\mathrm{P}<0.05$.

\section{Results}

Effects of QT supplementation to dairy cows at the transition period on DMI, milk yield, fat corrected milk (FCM), energy corrected milk (ECM) and feed efficiency (FE) are shown in Table 2, however milk yield profiles during early lactation due to QT supplementation is shown in Figure 2. The results revealed non-significant changes ( $\mathrm{P}>0.05)$ on DMI due to QT supplementation at the transition period of dairy cows. The roughage to concentrate ratio was 62.6:37.4, 61.2:38.8 and 62.3:37.7 for the control, $\mathrm{QT}_{100}$ and $\mathrm{QT}_{200}$, respectively. Supplementing dairy cows with 100 or $200 \mathrm{~g}$ QT decreased $(\mathrm{P}<0.05)$ daily milk yield from 30.17 to 26.34 and $25.92 \mathrm{~kg} /$ cow $/ \mathrm{d}$ for control, $\mathrm{QT}_{100}$ and $\mathrm{QT}_{200}$, respectively. Likewise, QT decreased $(\mathrm{P}<0.05)$ feed efficiency of dairy cows. The reduction in milk yield due to $\mathrm{QT}_{100}$ and $\mathrm{QT}_{200}$ was 13 and $14.2 \%$, respectively.

Table 2. Effect of QT supplementation $\times$ week on dry matter intake, milk yield and feed efficiency of early lactating dairy cows (Means \pm SE).

\begin{tabular}{ccccccc}
\hline & & & & \multicolumn{3}{c}{ P values } \\
\cline { 5 - 7 } Items & Control & $\mathrm{QT}_{100}$ & $\mathrm{QT}_{200}$ & $\mathrm{~W}$ & $\mathrm{~T}$ & $\mathrm{~W} \times \mathrm{T}$ \\
\hline DMI, kg/d & 21.10 & 20.71 & 20.60 & - & - & - \\
MY, kg/d & $30.2 \pm 0.96^{\mathrm{a}}$ & $26.3 \pm 1.03^{\mathrm{b}}$ & $25.9 \pm 0.99^{\mathrm{b}}$ & 0.0080 & 0.0035 & 0.8161 \\
FCM, kg/d & $26.8 \pm 1.02^{\mathrm{a}}$ & $24.0 \pm 1.11^{\mathrm{ab}}$ & $23.5 \pm 1.02^{\mathrm{b}}$ & 0.0038 & 0.0362 & 0.5974 \\
ECM, kg/d & $29.4 \pm 1.15$ & $27.2 \pm 1.24$ & $26.8 \pm 1.20$ & 0.0332 & 0.1482 & 0.8220 \\
FE, kg milk/kg DMI & $1.43 \pm 0.05^{\mathrm{a}}$ & $1.27 \pm 0.05^{\mathrm{b}}$ & $1.26 \pm 0.05^{\mathrm{b}}$ & 0.0078 & 0.0156 & 0.8163 \\
\hline
\end{tabular}

Means with different superscripts in the same row significantly differ $(\mathrm{P}<0.05)$; DMI: dry matter intake; MY: milk yield; FCM: fat corrected milk; ECM: energy corrected milk; FE: feed efficiency; W: weeks; T: treatment; SE: standard error. 
Similar reductions were found in other parameters. The corresponding decreases in FCM, ECM, FE and DMI were 10.5 and $12.3 \%, 7.5$ and $8.9 \%, 11.2$ and $11.9 \%$ and 1.9 and $1.9 \%$ due to QT100 and $\mathrm{QT}_{200}$, respectively.

Table 3 exhibits effect of various levels of QT supplementation to lactating dairy cow on milk composition. Supplementation of QT had none significant $(\mathrm{P}>0.05)$ effects on percentages of milk fat and lactose and on yields of fat, protein and SNF compared to the control. On the other hand, milk protein percentage increased $(\mathrm{P}<0.05)$ in $\mathrm{QT}_{100}$ (3.59\%), $\mathrm{QT}_{200}$ (3.48\%) compared with control (3.29\%) cows.

Likewise, percentage of SNF increased $(\mathrm{P}<0.05)$ with QT supplementation $(8.35 \%$, $8.83 \%$ and $8.67 \%$ in QT100, QT200 and C, respectively). Contrariwise, the yield of lactose decreased in milk of QT supplemented-cows. The increase in percentage of milk protein was higher in $\mathrm{QT}_{100}$ than in $\mathrm{QT}_{200}$. Contrariwise, lactose yield showed linear decrease by increasing QT level. Milk density increased $(\mathrm{P}<0.05)$ at $\mathrm{QT}_{100}$ but not at

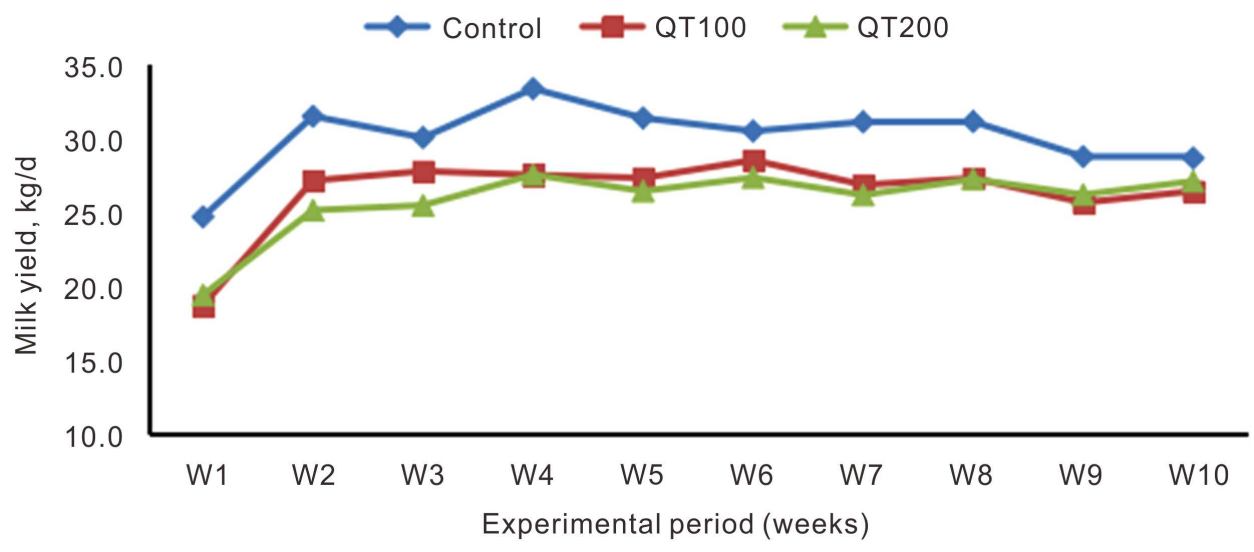

Figure 2. Effect of QT supplementation $\times$ week on milk yield profiles of early lactating dairy cows.

Table 3. Effect of QT supplementation $\times$ week on milk composition of early lactating dairy cows (Means \pm SE).

\begin{tabular}{|c|c|c|c|c|c|c|}
\hline \multirow{2}{*}{ Item } & \multirow{2}{*}{ Control } & \multirow{2}{*}{$\mathrm{QT}_{100}$} & \multirow{2}{*}{$\mathrm{QT}_{200}$} & \multicolumn{3}{|c|}{$\mathrm{P}$-value } \\
\hline & & & & $\mathrm{W}$ & $\mathrm{T}$ & $\mathrm{W} \times \mathrm{T}$ \\
\hline Fat, \% & $3.35 \pm 0.08$ & $3.35 \pm 0.08$ & $3.30 \pm 0.07$ & 0.004 & 0.778 & 0.018 \\
\hline Fat yield (g/d) & $1010.8 \pm 42.55$ & $882.5 \pm 46.24$ & $855.4 \pm 42.34$ & 0.002 & 0.064 & 0.351 \\
\hline Protein, \% & $3.29 \pm 0.04^{c}$ & $3.59 \pm 0.04^{\mathrm{a}}$ & $3.48 \pm 0.04^{\mathrm{b}}$ & $<0.001$ & $<0.001$ & $<0.001$ \\
\hline SNF, \% & $8.35 \pm 0.09^{b}$ & $8.83 \pm 0.09^{\mathrm{a}}$ & $8.67 \pm 0.096^{\mathrm{a}}$ & 0.001 & 0.001 & 0.225 \\
\hline SNF yield (g/d) & $2519.2 \pm 0.09$ & $2325.8 \pm 0.09$ & $2247.3 \pm 0.10$ & 0.065 & 0.110 & 0.818 \\
\hline Lactose, \% & $4.31 \pm 0.06$ & $4.30 \pm 0.06$ & $4.26 \pm 0.06$ & 0.954 & 0.836 & 0.455 \\
\hline Lactose yield (g/d) & $1300.3 \pm 43.72^{\mathrm{a}}$ & $1132.6 \pm 48.65^{\mathrm{b}}$ & $1104.2 \pm 47.29^{\mathrm{b}}$ & 0.045 & 0.029 & 0.892 \\
\hline
\end{tabular}

Means with different superscripts in the same row significantly differ $(\mathrm{P}<0.05)$; SNF: solid nonfat; W: weeks; T: treatment; SE: standard error. 
$\mathrm{QT}_{200}$. There found significant $(\mathrm{P}<0.05)$ time by treatment interaction on the milk fat, protein and density. Week of postpartum milking exhibits significant effects $(\mathrm{P}<0.05)$ on all milk attributes except percentage of lactose and density.

As shown in Table 4, there found trends of reductions in most ovarian structures and blood progesterone level. Despite these trends of reductions accompanied by the increase of QT level, the differences were not statistically significant $(\mathrm{P}>0.05)$.

Fertility data are shown in Table 5 . The results revealed that supplementing dairy cows with QT at levels of 100 and $200 \mathrm{~g}$ increased days open and number of services per conception but decreased the conception rate relative to the control group.

Results in Table 6 show that the treatment with $\mathrm{QT}_{100}$ decreased $(\mathrm{P}<0.05)$ serum total protein concentration relative to control group, while postpartum week of milk sample had no significant effect on blood protein. No significant effects were found due to QT supplementation on blood albumin, urea, creatinine and cholesterol. However, $\mathrm{QT}_{100}$ decreased $(\mathrm{P}<0.05)$ globulins, glucose and triglycerides. On the other hand, $\mathrm{QT}_{200}$ didn't change values of globulins, glucose and triglycerides than control. Furthermore, the time by treatment interactions were statistically significant on total protein, albumin, globulins and urea. All blood measured attributes, except protein were affected by the week of milking.

Table 4. Effect of QT supplementation on ovarian follicular dynamics and progesterone level of early lactating dairy cows (Mean \pm SE).

\begin{tabular}{cccc}
\hline Item & Control & $\mathrm{QT}_{100}$ & $\mathrm{QT}_{200}$ \\
\hline TNF & $8.6 \pm 0.90$ & $7.5 \pm 0.90$ & $6.4 \pm 0.90$ \\
NLF & $6.3 \pm 0.64$ & $5.9 \pm 0.64$ & $5.4 \pm 0.64$ \\
MDLF $(\mathrm{mm})$ & $11.41 \pm 0.56$ & $10.82 \pm 0.56$ & $10.86 \pm 0.56$ \\
NSF & $2.3 \pm 0.63$ & $1.6 \pm 0.63$ & $1.0 \pm 0.63$ \\
NCL & $0.9 \pm 0.17$ & $0.6 \pm 0.17$ & $0.6 \pm 0.17$ \\
DCL $(\mathrm{mm})$ & $15.97 \pm 3.17$ & $10.94 \pm 3.17$ & $12.13 \pm 3.17$ \\
Progesterone $(\mathrm{ng} / \mathrm{mL})$ & $2.40 \pm 0.470$ & $1.85 \pm 0.52$ & $1.52 \pm 0.56$
\end{tabular}

TNF: total number of follicles; NLF: number of large follicles; MDLF: means of diameter of large follicles; NSF: number of small follicles; NCL: number of corpus luteum; DCL: diameter of corpus luteum; SE: standard error.

Table 5. Effect of QT supplementation on reproductive performance of early lactating dairy cows.

\begin{tabular}{cccc}
\hline Item & Control & $\mathrm{QT}_{100}$ & $\mathrm{QT}_{200}$ \\
\hline Days open (d) & 125.0 & 210.0 & 225.0 \\
Number services per conception & 2.7 & 3.5 & 3.7 \\
Conception rate (\%) & 53.2 & 45.6 & 44.5 \\
\hline
\end{tabular}


Table 6. Effect of QT supplementation $\times$ week on blood metabolites of early lactating dairy cows (Mean \pm SE).

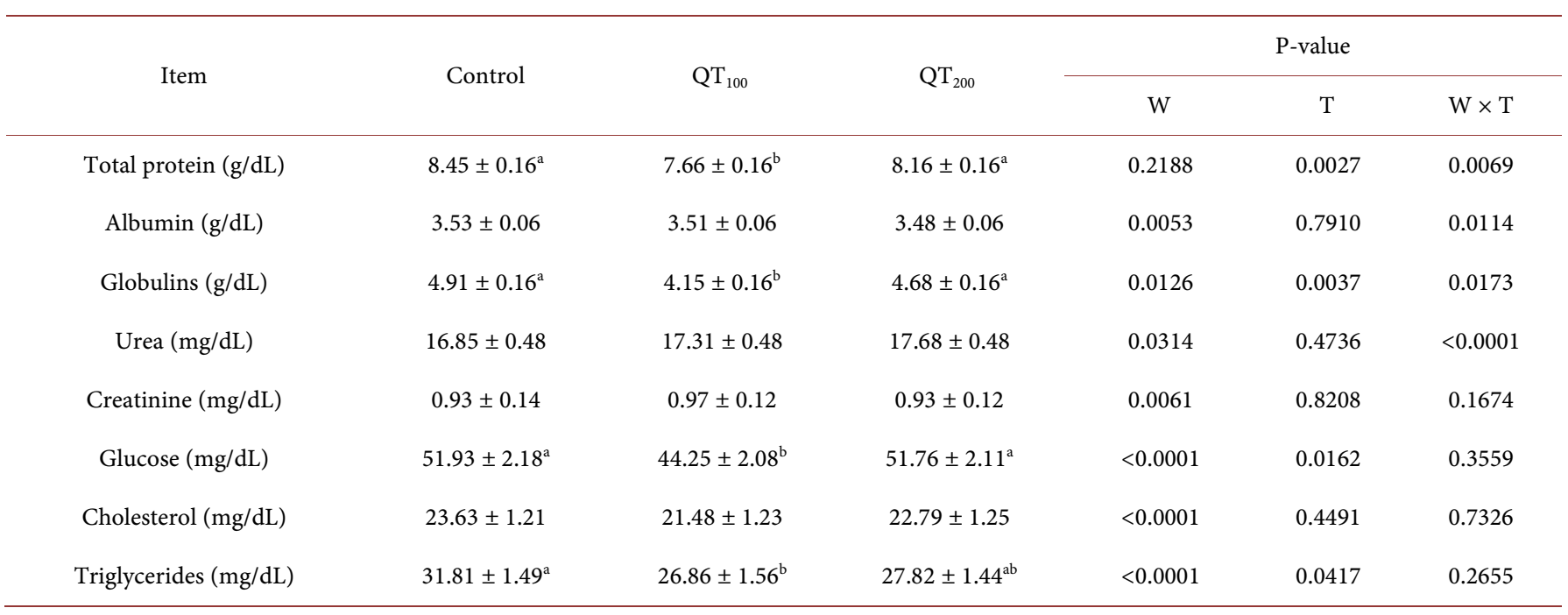

Means with different superscripts $(\mathrm{a}, \mathrm{b})$ in the same row significantly differ $(\mathrm{P}<0.05)$; W: time; T: treatment; SE: standard error.

\section{Discussion}

A unique chemical property of tannins is their affinity to bind nutrients and thereby reduce excessive breakdown in the rumen. Tannins may have beneficial or detrimental effects on ruminant nutrition depending on type, quantity consumed, compound structure, molecular weight and the physiological status of the consuming species [23]. It is important to remember that any quantity to be consumed should be taken with great caution. Also, different analytical methods, and different standards (e.g., quebracho, tannic acid, catequin, cyanidin, delphinidin, or internal standards from the plant itself etc.) may provide very different and therefore ambiguous results [24] [25]. Moreover, effects of tannins are directly dependent upon their quantitative presence in legumes, but there are differences among tannins depending on their reactivity which is related to their chemical nature and the type of association with the substrate [26].

Addition of the tannins to ruminant diets usually reduces feed intake because of reduced palatability, decreased rate of digestion and development of conditioned aversion [27]. Many mammals are able to produce Proline-Rich Proteins (PRP) in saliva that are able to bind to dietary tannins to inactivate them [28]. It is the binding of PRP and tannins that produces the astringent taste [29] and subsequent food avoidance. Cattle and sheep are devoid of PRP [30], so the decrease in DMI due to astringent taste mechanism associated with tannins may not occur in sheep and cattle. However, other proteins are present in the saliva of cattle fed tannin-rich diets which have a high affinity for tannins but are not rich in proline; these salivary proteins tend to form tannin-protein complexes [30].

Barry and Forss [31] find that in concentrations greater than $50 \mathrm{~g} / \mathrm{kg} \mathrm{DM}$, tannins can decrease feed intake and this limits the use of alternative feed resource even though they may have a high protein content suited to improve reproduction. Dietary tannins generally tend to decrease DMI. Hervás et al. [32] reported that intra-ruminally dosing 
ewes with QT at $3 \mathrm{~g} / \mathrm{kg}$ BW while fed alfalfa hay had a 95\% reduction in DMI after $3 \mathrm{~d}$ of dosing. Reduced DMI is thought to be caused by the astringent taste and decreased palatability possibly resulting in feed avoidance [33]. Decreases of DMI with CT have been already reported either in cows [34] [35] with or in sheep [36]. This depressing effect would be attributed to reduced palatability [37] or to short-term effect of astringency [38]. Therefore, the reduction of DMI in the current study might be due to a negative feedback of tannins astringency on palatability.

Alternatively, there found opposite effects due to tannin supplementation on DMI. In some cases, there existed increases in DMI due to tannin supplementation [39]-[41]. In cattle fed 70\% forage ration supplemented with QT, Beauchemin et al. [41] reported no adverse effect on DMI. However, Puchala et al. [40] reported increased DMI and decreased methane emissions in Angora does fed Lespedeza cuneata (CT-containing forage) vs. a mixture of Digitaria ischaemum and Festuca arundinacea. Additionally, late lactation dairy cows consuming Lotus corniculatus (CT-containing forage) had higher DMI and lower methane per unit milk compared to cows fed ryegrass silage. DMI increases were also observed with CT by Woodward et al. [39] and Carulla et al. [42] by using $2.59 \%$ and $2.50 \%$ of CT, respectively.

In accordance with our finding, no adverse effects of CT on DMI were found either on Jersey heifers ( $0.60 \%$ of QT; Baah et al. [43]) and lactating dairy cows ( $0.45 \%$ of CT, Benchaar et al. [44]). These results suggest that CT fed at relatively high concentrations has negative effects on feed intake in ruminants, and the effects may vary with the source of CT.

Addition of tannins to dairy diets usually reduces feed intake because of reduced palatability, decreased rate of digestion and development of conditioned aversion [27]. Also, milk yield, milk fat and protein reduced in dairy cows fed daily CT [45]. In contrast, Wang et al. [46] reported that tannins from Lotus corniculatus fed to lactating ewes increased milk yield, lactose and protein content. One of the reasons for these effects could be an increase in metabolizable protein supply from the protein binding action of CT [47] because effects of tannins on ruminant productivity depended on the quality and quantity of dietary protein.

The decrease of milk yield by QT supplementations in the present study is in agreement with the finding of Maamouri et al. [48] in ewes, whereas acacia supply does not improve $(\mathrm{P}>0.05)$ milk production. The protection of protein from microbial degradation in the rumen by tannins of the acacia did not result in milk increase. Contrariwise, other studies revealed that protein protection from microbial degradation resulted in an increase of milk production in cows [49], dairy goats [50] and sheep [51].

These results did not support the finding of Waghorn et al. [52] who claimed that the presence of CT at dietary concentrations below approximately $100 \mathrm{~g} / \mathrm{kg} \mathrm{DM}$ in the diet may increase ruminant's performance. In such a situation, protein protection could not have favorable conditions to improve milk production. These results did not agree with those of Wang et al. [46] in dairy sheep and Woodward et al. [49] in dairy cows who suggested that protein content increased with tannin administration in the diet. 
Moreover, our results partly agree with Benchaar et al.'s [44] findings which reported that inclusion of QT extract in the diet of dairy cows neither altered DM intake nor milk production or composition. Additionally, in grazing dairy ewes, Molle et al. [53] found no effect of the CT of Hedysarum coronarium on feed intake, but milk yield tended to be reduced and milk fat content was lower. Apparently, these inconsistent findings are probably related to ruminant species, physiological stage and type of tannins and dose. A key issue when using plant extracts as feed additives is dosage. Most doses of tannins evaluated in the studies quoted above are of a range from $4.5 \mathrm{~g} / \mathrm{kg} \mathrm{DM}$ [44] to $44.5 \mathrm{~g} / \mathrm{kg} \mathrm{DM} \mathrm{[46].} \mathrm{Furthermore,} \mathrm{the} \mathrm{lack} \mathrm{of} \mathrm{standardization} \mathrm{of} \mathrm{analysis} \mathrm{of} \mathrm{this}$ group of phenolic compounds and the use of different standards to express tannin concentrations mean that experiment comparisons can seldom be made with reasonable confidence [30]-[54].

Current study revealed that yield of milk components, concentrations of milk fat, true protein and lactose were not affected by QT supplementation. Milk fat yield and composition were not affected when supplementing CT in lactating dairy cow's diets up to $1.8 \%$ DM [55]. Moreover, Benchaar et al. [44] reported that milk composition was not changed when supplementing QT to lactating dairy cows. When supplementing CT at different levels, Aguerre et al. [55] reported that milk true protein concentration increased at $0.45 \%$ CT supplementation, while supplementing CT at $1.8 \%$ DM decreased milk true protein. It seems that milk composition depends on concentration of CT in the diet tested, and in the current study CT supplementation at 100 and $200 \mathrm{~g} / \mathrm{DM}$ results in minor changes on milk composition.

Dschaak et al. [56] determined the influence of QT on lactation performance of dairy cows. The cows were fed High Forage (HF) or Low Forage (LF) diet with forage to concentrate ratio of 59:41 or 41:59 on DM basis, respectively. Four dietary treatments were tested: HF without QT, HF with QT (HF + QT), LF without QT, and LF with QT $(\mathrm{LF}+\mathrm{QT})$. The QT was added to the HF + QT and the $\mathrm{LF}+\mathrm{QT}$ at a rate of $3 \%$ of dietary DM. Regardless of forage level, supplementing QT decreased DMI. So, the negative effects of QT supplementation on feed intake resulted in increased feed efficiency (milk yield/DMI). On contrast to our data, even in LF diets of dairy cows or HF diets of Egyptian buffaloes, Dschaak et al. [56] reported that milk yield averaged 34.6 and 36.1 $\mathrm{kg} / \mathrm{d}$ for the HF and LF diets, respectively, being not influenced by QT supplementation. In addition, Dschaak et al. [56] reported that concentrations of milk fat, true protein and lactose were not affected by QT supplementation. Concentration of Milk Urea Nitrogen (MUN) decreased with supplementing QT. Thus, it is clear that forming CTprotein complexes resulted in decreased protein degradation and $\mathrm{NH}_{3}-\mathrm{N}$ production in the rumen leading to a reduced MUN concentration. Although concentration of MUN decreased by supplementing QT in the diets, efficiency of $\mathrm{N}$ use for milk $\mathrm{N}$ was not affected by QT supplementation.

There are few studies on the impact of tannins-rich plants or extracts on the reproductive performance of adult ruminants. However, short periods of improved nutrient supply before and during mating and reproduction have been known to affect ovula- 
tion rate. Also, it increased follicle's size and/or number [57], reduced related follicular atresia (Downing and Scaramuzzi, [58]), altered plasma gonadotrophin concentration (Smith, [59]) and increased ovarian sensitivity to gonadotrophins [58]. These effects probably occur as a result of changes in live weight and body condition, energy and protein intake and protein absorption from the small intestine [15] [60] [61], plasma concentration of Essential Amino Acids (EAA) principally Branched-Chain Amino Acids (BCAA) [62]-[64] and levels of plasma metabolic hormones especially insulin [64].

A large part of the dietary protein is hydrolyzed in the rumen to ammonia, some of which is re-incorporated into microbial protein. Excess ammonia is absorbed from the rumen and metabolized to urea in the liver, leading to increased plasma ammonia and urea concentrations [15] which may increase the number of early embryonic losses [65]. In other studies, increased dietary Rumen Degradable Nitrogen (RDN) intake has similarly increased plasma urea concentration, leading to increased concentration of ammonia and urea in plasma in the utero-oviductal microenvironment [66] and uterine secretions [67], decreased uterine $\mathrm{pH}$ [68] impaired viability of sperm [69] and oocyte [70], decreased fertilization rate and reduced embryo survival and embryonic development in cows [71] and ewes [72].

Thus, subsequent grazing experiments with sheep showed that CT in L. corniculatus increased both ovulation rate and lambing percentage by $20 \%-27 \%$ [61]. Effects of CT revealed reduced rumen protein degradation to ammonia, increased EAA absorption and reduced early embryonic losses [15]. In New Zealand, an alternative pasture species, Lotus corniculatus has recently been investigated [15]-[73]. The studies compared ewes grazing $L$. corniculatus with ewes grazing a perennial ryegrass/white clover pasture, and found that $L$. corniculatus caused a $5 \%-33 \%$ increase in ovulation rate (maximized if L. corniculatus was fed for 2 - 3 estrus cycles before mating), a 6\% - 39\% increase in lambing percentage, and a $14 \%-26 \%$ increase in weaning percentage. The effect of Lotus on ovulation rate was at least partly dependent on the concentration of active tannins. Other effects may include a reduction in the concentration of rumen and plasma ammonia and plasma urea [15] or changes in the environment of the oviduct and uterus that are conducive to conception, implantation, and fetal development [13]. Finally, it is important to stress that the concentration of tannins has to be low to improve reproduction. Whereas, high tannin concentrations can be detrimental to reproduction [15].

Data of blood biochemical constituents were within the normal range of variation reported for healthy ruminants [74]. This shows that the addition of QT supplementation on diets did not cause major health disorders. Plant secondary compounds may affect blood parameters by maintaining them [75], while others may decrease [76] or increase [77] plasma glucose concentration, or alter serum insulin concentration [78].

Mahgoub et al. [79] found increases in CT-fed sheep serum ALT and phosphorus, whereas decreases in AST, glucose, iron, urea, haematocrit, lymphocyte, monocyte and eosinophil were found. Total protein, albumin and creatinin were not significantly af- 
fected. All these alterations might produce subtle negative effects on the physiology and chemistry of the digestive system and blood parameters which might negatively affect sheep health and make them more susceptible to diseases.

Plant secondary compounds can cause hemolysis and anemia [80], although some plants and compounds may also act as anticoagulants [81]. Bioactive plant compounds have been reported to enhance immune function of animals, with effects ranging from anti-inflammatory [82], enhanced humoral and cellular immunity, to modulation of immune pathways, specific receptors, enzymes and immune molecules [83] [84].

Rezaeenia et al. [85] reported that inclusion of 15\% PBP (5.5\% DM, tannins) in the diet of early lactation-dairy cows had no effects on their serum glucose, blood urea nitrogen (BUN), and cholesterol. Similar results were reported by Bohluli et al. [86] for serum glucose and BUN in early lactation dairy cows. However, Gholizadeh et al. [87] reported that inclusion of $10 \%$ PBP in the diet of dairy cows had no effects on their blood cholesterol, BUN, triglyceride, and glucose.

Recently, Ghaffari et al. [88] revealed that the use of 30\% PBP as a source of tannins in replacement of alfalfa hay in the diet of dairy Saanen goats showed no differences in blood metabolites. Woodward [89] had shown that plasma urea nitrogen was lower when sheep and goats were fed legumes that contained tannins. Sheep fed pure diets of L. pedunculatus had lower plasma urea concentrations, a more rapid plasma urea turnover rate and a higher irreversible loss than sheep receiving $L$. pedunculatus that was treated with polyethylene glycol to deactivate the tannins [90]. Ben Salem et al. [91] reported that acacia supply decreased plasma urea, ruminal $\mathrm{NH}_{3}-\mathrm{N}$ and in situ degradation of soya bean meal. Furthermore, reduced proteolysis in ewes receiving acacia cyanophylla with concentrate could have been caused by effects of acacia tannins on microbial proteolytic activity [92].

The culmination of the data of this study revealed that the controversy in the literature of the ability of tannins to modulate rumen fermentation, nutrients utilization and performance of ruminants was probably due to the great diversity in the structural features and consequently, the reactivity of these PSC. The dose-dependent effect of tannins is another major issue because of the difficulty in selecting concentrations to positively affect a particular parameter without conferring a negative response in others (e.g., in overall diet utilization). Moreover, the percentage of the RDP at the investigated diets either in vitro or in vivo trails was not so high and probably may not require more protection by binding with tannins.

Supplementation of commercial QT to dairy cattle had negative impacts on productive and reproductive performance at the transition period. More experiments using different proportions of RDP and RUP for specific judgment on the impacts of commercial QT in ruminant diets are warranted to be done.

\section{Acknowledgements}

Authors gratefully acknowledge the financial support provided by the Alex Rep project, Alexandria University, Code No. AGRV-09, without which this work wouldn't have 
been appeared.

\section{References}

[1] OJEU (2003) Regulation (EC) No. 1831/2003 of European Parliament and the Council of 22 September 2003 on Additives for Use in Animal Nutrition. Page L268/36 in OJEU of 10/18/2003, Off. J. Eur. Union, Brussels.

[2] Calsamiglia, S., Busquet, M., Cardozo, P.W., Castillejos, L. and Ferret, A. (2007) Essential Oils as Modifiers of Rumen Microbial Fermentation. Journal of Dairy Science, 90, 25802595. http://dx.doi.org/10.3168/jds.2006-644

[3] Makkar, H.P.S., Norvsambuu, T., Lkhagvatseren, S. and Becker, K. (2009) Plant Secondary Metabolites in Some Medicinal Plants of Mongolia Used for Enhancing Animal Health Production. Tropicultura, 27, 159-167.

[4] Blumenthal, M. (2003) The ABC Clinical Guide to Herbs. American Botanical Council, Austin.

[5] Bodas, R., Prieto, N., García-González, R., Andrés, S., Giráldez, F.J. and López, S. (2012) Manipulation of Rumen Fermentation and Methane Production with Plant Secondary Metabolites. Animal Feed Science and Technology, 176, 78-93. http://dx.doi.org/10.1016/j.anifeedsci.2012.07.010

[6] Haslam, E. and Lilley, T.H. (1988) Natural Astringency in Foodstuffs. Critical Reviews in Food Science and Nutrition, 27, 1-40. http://dx.doi.org/10.1080/10408398809527476

[7] Getachew, G., Makkar, H.P.S. and Becker, K. (2000) Effect of Polyethylene Glycol on in Vitro Degradability of Nitrogen and Microbial Protein Synthesis from Tannin-Rich Browse and Herbaceous Legumes. British Journal of Nutrition, 84, 73-83.

[8] Waghorn, M.J., Ulyatt, A.J. and Fisher, T. (1987) The Effect of Condensed Tannins on the Site of Digestion of Amino Acids and Other Nutrients in Sheep Fed on Lotus corniculatus L. British Journal of Nutrition, 57, 115-126. http://dx.doi.org/10.1079/BJN19870015

[9] Min, B.R., Attwood, G.T., McNabb, W.C., Molan, A.L. and Barry, T.N. (2005) The Effect of Condensed Tannins from Lotus corniculatus on the Proteolytic Activities and Growth of Rumen Bacteria. Animal Feed Science and Technology, 121, 45-58. http://dx.doi.org/10.1016/j.anifeedsci.2005.02.007

[10] Tanner, G.J., Moate, P.J., Davis, L.H., Laby, R.H., Li, Y., Larkin, P.J. and Li, Y. (1995) Proanthocyanidins (Condensed Tannin) Destabilise Plant Protein Foams in a Dose Dependent Manner. Australian Journal of Agricultural Research, 48, 1101-1109. http://dx.doi.org/10.1071/AR9951101

[11] Lapierre, H., Berthiaume, R. and Dubreuil, P. (2002) Equilibrer les rations pour les acides aminés: Rêve ou réalité. 26ème Symposium sur les bovins laitiers. CRAAQ. Université de Sherbrooke, Sherbrooke, 12-29.

[12] Min, B.R. and Hart, S.P. (2003) Tannins for Suppression of Internal Parasites. Journal of Animal Science, 81, E102-E109.

[13] Ramirez-Restrepo, C.A. and Barry, T.N. (2005) Alternative Temperate Forages Containing Secondary Compounds for Improving Sustainable Productivity in Grazing Ruminants. Animal Feed Science and Technology, 120, 179-201. http://dx.doi.org/10.1016/j.anifeedsci.2005.01.015

[14] Min, B.R., Pomroy, W.E., Hart, S.P. and Sahlu, T. (2004) The Effect of Short-Term Consumption of a Forage Containing Condensed Tannins on Gastrointestinal Nematode Parasite Infections in Grazing Wether Goats. Small Ruminant Research, 51, 279-283. 
http://dx.doi.org/10.1016/S0921-4488(03)00204-9

[15] Min, B.R., Attwood, G.T., McNabb, W.C. and Barry, T.N. (2001) Effect of Condensed Tannins on Proteolytic Bacterial Populations in the Rumen and on Nitrogen Flow to the Abomasum of Sheep. Journal of Animal Science, 79, 163.

[16] Min, B.R., Barry, T.N., Attwood, G.T. and McNabb, W.C. (2003) The Effect of Condensed Tannins on the Nutrition and Health of Ruminants Fed Fresh Temperate Forages: A Review. Animal Feed Science and Technology, 106, 3-19. http://dx.doi.org/10.1016/S0377-8401(03)00041-5

[17] NRC (2001) Nutrient Requirements of Dairy Cattle. 7th Edition, National Academy of Science, Washington DC.

[18] AOAC (2006) Official Methods of Analysis of AOAC International (2000). 20th Edition, AOAC, Arlington, VA.

[19] Van Soest, P.J., Robertson, J.B. and Lewis, B.A. (1991) Methods for Dietary Fibre, Neutral Detergent Fibre, and Nonstarch Polysaccharides in Relation to Animal Nutrition. Journal of Dairy Science, 74, 3583-3597. http://dx.doi.org/10.3168/jds.S0022-0302(91)78551-2

[20] Robertson, J.B. and Van Soest, P.J. (1981) The Detergent System of Analysis. In: James, W.P.T. and Theander, O. (Eds.), The Analysis of Dietary Fibre in Food, Chapter 9, Marcel Dekker, New York, 123-158.

[21] www.feedipedia.org

[22] SAS (2002) SAS Users Guide. Statistical Analyses Systems Institute, Cary, 549-640.

[23] Hagerman, A.E. and Butler, L.G. (1991) Tannins and Lignins. In: Rosenthal, G.A. and Berenbaum, M.R., Eds., Herbivores. Their Interactions with Secondary Plant Metabolites, Vol. I: The Chemical Participants, Academic Press, New York, 355-388. http://dx.doi.org/10.1016/B978-0-12-597183-6.50015-2

[24] Schofield, P., Mbugua, D.M. and Pell, A.N. (2001) Analysis of Condensed Tannins: A Review. Animal Feed Science and Technology, 91, 21-40. http://dx.doi.org/10.1016/S0377-8401(01)00228-0

[25] Frutos, P., Raso, M., Hervás, G., Mantecón, A.R., Pérez, V. and Giráldez, F.J. (2004) Is There Any Detrimental Effect When a Chestnut Hydrolyzable Tannins Extract Is Included in the Diet of Finishing Lambs? Animal Research, 53, 127-136. http://dx.doi.org/10.1051/animres:2004001

[26] Bueno, I.C.S., Vitti, D.M.S.S., Louvandini, H. and Abdalla, A.L. (2008) A New Approach for in Vitro Bioassay to Measure Tannin Biological Effects Based on a Gas Production Technique. Animal Feed Science and Technology, 141, 153-170. http://dx.doi.org/10.1016/j.anifeedsci.2007.04.011

[27] Mueller-Harvey, I. (2006) Unravelling the Conundrum of Tannins in Animal Nutrition and Health. Journal of the Science of Food and Agriculture, 86, 2010-2037. http://dx.doi.org/10.1002/jsfa.2577

[28] Austin, P.J., Suchar, L.A., Robbins, C.T. and Hagerman, A.E. (1989) Tannin-Binding Proteins in Saliva of Deer and Their Absence in Saliva of Sheep and Cattle. Journal of Chemical Ecology, 15, 1335-1347. http://dx.doi.org/10.1007/BF01014834

[29] Prinz, J.F. and Lucas, P.W. (2000) Saliva Tannin Interactions. Journal of Oral Rehabilitation, 27, 991-994.

[30] Makkar, H.P.S. (2003) Effects and Fate of Tannins in Ruminant Animals, Adaptation to Tannins, and Strategies to Overcome Detrimental Effects of Feeding Tannin-Rich Feeds. Small Ruminant Research, 49, 241-256. http://dx.doi.org/10.1016/S0921-4488(03)00142-1 
[31] Barry, T.N. and Forss, D.A. (1983) The Condensed Tannin Content of Vegetative Lotus pedunculatus, Its Regulation by Fertiliser Application, and Effect upon Protein Solubility. Journal of the Science of Food and Agriculture, 34, 1047-1056. http://dx.doi.org/10.1002/jsfa.2740341004

[32] Hervás G., Frutos, P., Giráldez, F.J., Mantecón, A.R. and Álvarez del Pino, M.C. (2003) Effect of Different Doses of Quebracho Tannins Extract on Rumen Fermentation in Ewes. Animal Feed Science and Technology, 109, 65-78. http://dx.doi.org/10.1016/S0377-8401(03)00208-6

[33] Kumar, R. and Singh, M. (1984) Tannins: Their Adverse Role in Ruminant Nutrition. Journal of Agricultural and Food Chemistry, 32, 447-453. http://dx.doi.org/10.1021/jf00123a006

[34] McNabb, W.C., Waghorn, G.C., Peters, J.S. and Barry, T.N. (1996) The Effect of Condensed Tannins in Lotus pedunculatus on the Solubilization and Degradation of Ribulose-1,5-Bis Phosphate Carboxylase (EC 4.1.1.39; Rubisco) Protein in the Rumen and the Sites of Rubisco Digestion. British Journal of Nutrition, 76, 535-549. http://dx.doi.org/10.1079/BJN19960061

[35] Priolo, A., Waghorn, G.C., Lanza, M., Biondi, L. and Pennisi, P. (2000) Polyethylene Glycol as a Means for Reducing the Impact of Condensed Tannins in Carob Pulp: Effects on Lamb Growth, Performance and Meat Quality. Journal of Animal Science, 78, 810-816. http://dx.doi.org/10.2527/2000.784810x

[36] Barry, T.N. and McNabb, W.C. (1999) The Implications of Condensed Tannins on the Nutritive Value of Temperate Forages Fed to Ruminants. British Journal of Nutrition, 81, 263-272.

[37] Cooper, S.M. and Owen-Smith, N. (1985) Condensed Tannins Deter Feeding by Browsing Ungulates in a South African Savanna. Oecologia, 67, 142-146. http://dx.doi.org/10.1007/BF00378466

[38] Landau, S., Perevolotsky, A., Bonfil, D., Barkai, D. and Silanikove, N. (2000) Utilization of Low Quality Resources by Small Ruminants in Mediterranean Agro-Pastoral Systems: The Case of Browse and Aftermath Cereal Stubble. Livestock Production Science, 64, 39-49. http://dx.doi.org/10.1016/S0301-6226(00)00174-3

[39] Woodward, S.L., Waghorn, G.C., Ulyatt, M.J. and Lassey, K.R. (2001) Early Indications That Feeding Lotus Will Reduce Methane Emissions from Ruminants. Proceedings of the New Zealand Society of Animal Production, 61, 23-26.

[40] Puchala, R., Min, B.R., Goetsch, A.L. and Sahlu, T. (2005) The Effect of a Condensed Tannin-Containing Forage on Methane Emission by Goats. Journal of Animal Science, 83, 182 186. http://dx.doi.org/10.2527/2005.831182x

[41] Beauchemin, K.A., McGinn, S.M., Martinez, T.F. and McAllister, T.A. (2007) Use of Condensed Tannin Extract from Quebracho Trees to Reduce Methane Emissions from Cattle. Journal of Animal Science, 85, 1990-1996. http://dx.doi.org/10.2527/jas.2006-686

[42] Carulla, J.E., Kreuzer, M., Machmüller, A. and Hess, H.D. (2005) Supplementation of Acacia Mearnsii Tannins Decreases Methanogenesis and Urinary Nitrogen in Forage-Fed Sheep. Australian Journal of Agricultural Research, 56, 961-970. http://dx.doi.org/10.1071/AR05022

[43] Baah, J., Ivan, M., Hristov, A.N., Koenig, K.M., Rode, L.M. and McAllister, T.A. (2007) Effects of Potential Dietary Antiprotozoal Supplements on Rumen Fermentation and Digestibility in Heifers. Animal Feed Science and Technology, 137, 126-137. http://dx.doi.org/10.1016/j.anifeedsci.2006.11.004 
[44] Benchaar, C., Calsamiglia, S., Chaves, A.V., Fraser, G.R., Colombatto, D., McAllister, T.A. and Beauchemin, K.A. (2008) A Review of Plant-Derived Essential Oils in Ruminant Nutrition and Production. Animal Feed Science and Technology, 145, 209-228. http://dx.doi.org/10.1016/j.anifeedsci.2007.04.014

[45] Grainger, C., Clarke, T., Auldist, M.J., Beauchemin, K.A., McGinn, S.M. and Waghorn, G.C. (2009) Potential Use of Acacia mearnsii Condensed Tannins to Reduce Methane Emissions and Nitrogen Excretion from Grazing Dairy Cows. Canadian Journal of Animal Science, 89, 241-251. http://dx.doi.org/10.4141/CJAS08110

[46] Wang, Y., Douglas, G.B., Waghorn, G.C., Barry, T.N. and Foote, A.G. (1996) Effect of Condensed Tannins in Lotus corniculatus upon Lactation Performance in Ewes. The Journal of Agricultural Science, 126, 353-362. http://dx.doi.org/10.1017/S0021859600074918

[47] Patra, A.K. and Saxena, J. (2011) Exploitation of Dietary Tannins to Improve Rumen Metabolism and Ruminant Nutrition. Journal of the Science of Food and Agriculture, 91, 24-37. http://dx.doi.org/10.1002/jsfa.4152

[48] Maamouri, O., Atti, N., Kraiem, K. and Mahouachi, M. (2011) Effects of Concentrate and Acacia cyanophylla Foliage Supplementation on Nitrogen Balance and Milk Production of Grazing Ewes. Livestock Science, 139, 264-270. http://dx.doi.org/10.1016/j.livsci.2011.01.018

[49] Woodward, S.L., Auldist, M.J., Laboyrie, P.J. and Jansen, E.B.L. (1999) Effect of Lotus corniculatus and Condensed Tannins on Milk Yield and Milk Composition of Dairy Cows. Proceedings of the New Zealand Society of Animal Production, 59, 152-155.

[50] Rouissi, H., Atti, N., Mahouachi, M. and Rekik, B. (2006) Effet de la complementation azotée sur les performances zootechniques de la chèvre locale. Tropicultura, 24, 111-114.

[51] Penning, P.D., Orr, R.J. and Treacher, T.T. (1988) Responses of Lactating Ewes Offered Fresh Herbage Indoors and When Grazing, to Supplements Containing Differing Protein Concentrations. Animal Production, 46, 403-415.

http://dx.doi.org/10.1017/S0003356100019012

[52] Waghorn, G.C., Reed, J.D. and Ndlovu, L.R. (1999) Condensed Tannins and Herbivore Nutrition. In: Buchanan-Smith, J.G., Bailey, L.D. and McCaughey, P., Eds., Proceedings of the XVIII International Grasslands Congress, Association Management Centre, Calgary, Alberta, 153-166.

[53] Molle, G., Decandia, M., Giovanetti, V., Cabiddu, A., Fois, N. and Sitzia, M. (2009) Responses to Condensed Tannins of Flowering Sulla (Hedysarum coronarium L.) Grazed by Dairy Sheep. Part 1: Effects on Feeding Behaviour, Intake, Diet Digestibility and Performance. Livestock Science, 123, 138-146. http://dx.doi.org/10.1016/j.livsci.2008.11.018

[54] Álvarez del Pino, M.C., Hervás, G., Mantecón, A.R., Giráldez, F.J. and Frutos, P. (2005) Comparison of Biological and Chemical Methods, and Internal and External Standards, for Assaying Tannins in Shrub Species. Journal of the Science of Food and Agriculture, 85, 583-590. http://dx.doi.org/10.1002/jsfa.1997

[55] Aguerre, M.J., Wattiaux, M.A., Capozzolo, M.C., Lencioni, P. and Cabral, C. (2010) Effect of Quebracho-Chestnut Tannin Extracts at Two Dietary Crude Protein Levels on Performance and Rumen Fermentation of Dairy Cows. Journal of Dairy Science, 93, 445. (Abstr.)

[56] Dschaak, C.M., Williams, C.M., Holt, M.S., Eun, J.S., Young, A.J. and Min, B.R. (2011) Effects of Supplementing Condensed Tannin Extract on Intake, Digestion, Ruminal Fermentation, and Milk Production of Lactating Dairy Cows. Journal of Dairy Science, 94, 2508-2519. http://dx.doi.org/10.3168/jds.2010-3818 
[57] Bellows, R.A., Pope, A.L., Meyer, R.K., Chapman, A.B. and Casida, L.E. (1963) Physiological Mechanisms in Nutritionally-Induced Differences in Ovarian Activity of Mature Ewes. Journal of Animal Science, 22, 93-100. http://dx.doi.org/10.2527/jas1963.22193x

[58] Downing, J.A. and Scaramuzzi, R.J. (1991) Nutrient Effects on Ovulation Rate, Ovarian Function and the Secretion of Gonadotrophic and Metabolic Hormones. Journal of Reproduction and Fertility, 43, 209-227.

[59] Smith, J.F. (1988) Influence of Nutrition on Ovulation Rate in the Ewe. Australian Journal of Biological Sciences, 41, 27-36.

[60] Smith, J.F. (1991) A Review of Recent Developments on the Effect of Nutrition on Ovulation Rate (the Flushing Effect) with Particular Reference to Research at Ruakura. Proceedings of the New Zealand Society of Animal Production, 51, 15-23.

[61] Min, B.R., McNabb, W.C., Barry, T.N., Kemp, P.D., Waghorn, G.C. and McDonald, M.F. (1999) The Effect of Condensed Tannins in Lotus corniculatus upon Reproductive Efficiency and Wool Production in Sheep during Late Summer and Autumn. The Journal of Agricultural Science, 132, 323-334. http://dx.doi.org/10.1017/S0021859699006371

[62] Waghorn, G.C. (1986) The Effect of Different Protein/Energy Intakes on Nutritional and Physiological Parameters in Young Sheep. Proceedings of the New Zealand Society of Animal Production, 46, 31-35.

[63] Waghorn, G.C., Jones, W.T., Shelton, I.D. and McNabb, W.C. (1990) Condensed Tannins and the Nutritive Value of Herbage. Proceedings of the New Zealand Grassland Association, 51, 171-176.

[64] Downing, J.A., Joss, J. and Scaramuzzi, R.J. (1995) A Mixture of the Branched Chain Amino Acids Leucine, Isoleucine and Valine Increases Ovulation Rate in Ewes When Infused during the Late Luteal Phase of the Oestrus Cycle: An Effect That May Be Mediated by Insulin. Journal of Endocrinology, 145, 315-323. http://dx.doi.org/10.1677/joe.0.1450315

[65] El-Zarkouny, S.Z., Ghobashy, H., Nour El-Din, A.N.M., Abdel-Gauad, E.I. and Hassan, G.A. (2007) Lambing and Embryonic Mortality Rates in Awassi and Barki Ewes and Their Crosses throughout Three Different Mating Seasons in the West Coastal Region of Egypt. Alexandria Journal of Agricultural Research, 52, 15-24.

[66] McEvoy, T.G., Robinson, J.J., Aitken, R.P., Findlay, P.A. and Robertson, I.S. (1997) Dietary Excesses of Urea Influence the Viability and Metabolism of Preimplantation Sheep Embryos and May Affect Fetal Growth among Survivors. Animal Reproduction Science, 47, 71-90. http://dx.doi.org/10.1016/S0378-4320(96)01627-2

[67] Jordan, E.R., Chapman, T.E., Holtan, D.W. and Swanson, L.V. (1983) Relation of Dietary Crude Protein to Composition of Uterine Secretions and Blood in High-Producing Postpartum Dairy Cows. Journal of Dairy Science, 66, 1854-1862. http://dx.doi.org/10.3168/jds.S0022-0302(83)82023-2

[68] Elrod, C.C. and Buttler, W.R. (1993) Reduction of Fertility and Alteration of Uterine pH in Heifers Fed Excess Ruminally Degradable Protein. Journal of Animal Science, 71, 694-701.

[69] Umezaki, C. and Fordney-Settlage, D.S. (1975) In Vitro Studies on Cervical Contraception: Use of Urea as Spermicidal Agent. Contraception, 12, 465-476. http://dx.doi.org/10.1016/0010-7824(75)90082-7

[70] O’Callaghan, D.O. and Boland, M.P. (1999) Nutritional Effects on Ovulation, Embryo Development and the Establishment of Pregnancy in Ruminants. Animal Science, 68, 299-314. http://dx.doi.org/10.1017/S1357729800050311

[71] Blanchard, T., Ferguson, J., Love, L., Takeda, T., Henderson, B., Hasler, J. and Chalupa, W. (1990) Effect of Dietary Crude-Protein Type on Fertilization and Embryo Quality in Dairy 
Cattle. American Journal of Veterinary Research, 51, 905-908.

[72] Fahey, J., Boland, M.P. and O’Callaghan, D.O. (1998) Effects of Dietary Urea on Embryo Development in Superovulated Donor Ewes and on Embryo Survival Following Transfer in Recipient Ewes. Proceedings of the British Society of Animal Science, 182.

[73] Ramirez-Restrepo, C.A., Barry, T.N., Lopez-Villalobos, N., Kemp, N. and Harvey, T.G. (2005) Use of Lotus corniculatus Containing Condensed Tannins to Increase Reproductive Efficiency in Ewes under Commercial Dryland Farming Conditions. Animal Feed Science and Technology, 121, 23-43. http://dx.doi.org/10.1016/j.anifeedsci.2005.02.006

[74] Blood, P.C., Radostits, O.M., Henderson, J.A., Arunded, J.H. and Gay, C.C. (1983) Veterinary Medicine. 6th Edition, ELBS and Bailliere, Tiridad, Eastbourne, 260-270.

[75] Raghuvansi, S.K., Prasad, R., Mishra, A.S., Chaturvedi, O.H., Tripathi, M.K., Misra, A.K., Saraswat, B.L. and Jakhmola, R.C. (2007) Effect of Inclusion of Tree Leaves in Feed on Nutrient Utilization and Rumen Fermentation in Sheep. Bioresource Technology, 98, 511517. http://dx.doi.org/10.1016/j.biortech.2006.02.008

[76] Joy, P.P., Thomas, J., Mathew, S. and Skaria, B.P. (2001) Medicinal Plants. In: Bose, T.K., Kabir, J., Das, P. and Joy, P.P., Eds., Tropical Horticulture, Naya Prokash, Calcutta, 449632.

[77] Mohammed, N., Ajisaka, N., Lila, Z.A., Hara, K., Mikuni, K., Kanda, S. and Itabashi, H. (2004) Effect of Japanese Horseradish Oil on Methane Production and Ruminal Fermentation in Vitro and in Steers. Journal of Animal Science, 82, 1839-1846. http://dx.doi.org/10.2527/2004.8261839x

[78] Devant, M., Anglada, A. and Bach, A. (2007) Effects of Plant Extract Supplementation on Rumen Fermentation and Metabolism in Young Holstein Bulls Consuming High Levels of Concentrate. Animal Feed Science and Technology, 137, 46-57. http://dx.doi.org/10.1016/j.anifeedsci.2006.10.003

[79] Mahgoub, O., Kadim, I.T., Tageldin, M.H., Al-Marzooqi, W.S., Khalaf, S.Q. and Ambu Ali, A. (2008) Clinical Profile of Sheep Fed Non-Conventional Feeds Containing Phenols and Condensed Tannins. Small Ruminant Research, 78, 115-122. http://dx.doi.org/10.1016/j.smallrumres.2008.05.009

[80] Bernhoft, A., (2010) A Brief Review. In: Bernhoft, A., Ed., Bioactive Compounds in Plants-Benefits and Risks for Man and Animals, The Norwegian Academy of Science and Letters, Oslo, Norway, 11-17.

[81] Dahanukar, S.A., Kulkarni, R.A. and Rege, N.N. (2000) Pharmacology of Medicinal Plants and Natural Products. Indian Journal of Pharmacology, 32, S81-S118.

[82] Neto, A.G., Costa, J.M., Belati, C.C., Vinholis, A.H., Possebom, L.S., Da Silva Filho, A.A., Cunha, W.R., Carvalho, J.C., Bastos, J.K. and Silva, M.L. (2005) Analgesic and AntiInflammatory Activity of a Crude Root Extract of Pfaffia glomerata (Spreng) Pedersen. Journal of Ethnopharmacology, 96, 87-91. http://dx.doi.org/10.1016/j.jep.2004.08.035

[83] Rao, K.S. and Mishra, S.H. (1997) Anti-Inflammatory and Hepatoprotective Activities of Sida rhombifolia Linn. Indian Journal of Pharmacology, 29, 110-116.

[84] More, P. and Pai, K. (2011) Immunomodulatory Effects of Tinospora cordifolia (Guduchi) on Macrophage Activation. Biology and Medicine, 3, 134-140.

[85] Rezaeenia, A., Naserian, A.A., Valizadeh, R. and Tahmasbi, A. (2012) Effect of Using Different Levels of Pistachio By-Products Silage on Composition and Blood Parameters of Holstein Dairy Cows. African Journal of Biotechnology, 11, 6192-6196.

[86] Bohluli, A., Naserian, A., Valizadeh, R. and Eftekhari, F. (2009) The Effect of Pistachio By-Product on Nutrient Apparent Digestibility, Rumination Activity and Performance of 
Holstein Dairy Cows in Early Lactation. Journal of Water and Soil Science, 13, 167-179.

[87] Gholizadeh, H., Naserian, A.A., Valizadeh, R. and Tahmasebi, A. (2010) Effect of Feeding Pistachio Byproduct on Performance and Blood Metabolites in Holstein Dairy Cows. International Journal of Agriculture and Biology, 12, 867-870.

[88] Ghaffari, M.H., Tahmasbi1, A., Khorvash, M., Naserian, A.A. and Vakili, A.R. (2014) Effects of Pistachio By-Products in Replacement of Alfalfa Hay on Ruminal Fermentation, Blood Metabolites, and Milk Fatty Acid Composition in Saanen Dairy Goats Fed a Diet Containing Fish Oil. Journal of Applied Animal Research, 42, 186-193.

[89] Woodward, A. (1988) Chemical Composition of Browse in Relation to Relative Consumption of Species and Nitrogen Metabolism of Livestock in Southern Ethiopia. Ph.D. Dissertation, Cornell University, Ithaca, NY.

[90] Waghorn, G.C., Shelton, I.D., McNabb, W.C. and McCutcheon, S.N. (1994) Effects of Condensed Tannins in Lotus pedunculatus on Its Nutritive Value for Sheep. 2. Nitrogenous Aspects. The Journal of Agricultural Science, 123, 109-119. http://dx.doi.org/10.1017/S0021859600067836

[91] Ben Salem, H., Makkar, H.P.S., Nefzaoui, A., Hassayoun, L. and Abidi, S. (2005) Benefit from the Association of Small Amounts of Tannin-Rich Shrub Foliage (Acacia cyanophylla Lindl.) with Soya Bean Meal Given as Supplements to Barbarine Sheep Fed on Oaten Hay. Animal Feed Science and Technology, 122, 173-186. http://dx.doi.org/10.1016/j.anifeedsci.2005.04.012

[92] Jones, G.A., Jakober, K.D., Bae, H.D., McAllister, T.A. and Cheng, K.J. (1993) Some Interactions between Condensed Tannins of Forage Legumes. Some Interactions between Condensed Tannins of Forage Legumes, Bovin Serum Albumin, and Five Strains of Proteolytic Rumen Bacteria. Proceedings of the World Conference on Animal Production, 36, 68-69.

\section{Submit or recommend next manuscript to SCIRP and we will provide best service for you:}

Accepting pre-submission inquiries through Email, Facebook, LinkedIn, Twitter, etc.

A wide selection of journals (inclusive of 9 subjects, more than 200 journals)

Providing 24-hour high-quality service

User-friendly online submission system

Fair and swift peer-review system

Efficient typesetting and proofreading procedure

Display of the result of downloads and visits, as well as the number of cited articles

Maximum dissemination of your research work

Submit your manuscript at: http://papersubmission.scirp.org/

Or contact ojas@scirp.org 